\title{
TPACK Knowledge Mastery of Pre-Service Teacher Students in the Faculty of Economics Universitas Negeri Medan
}

\author{
Indra Maipita $^{1 *}$, Faisal Rahman Dongoran ${ }^{1}$, Dedy Husrizal Syah ${ }^{1}$, Gaffar Hafiz \\ Sagala ${ }^{1}$
}

${ }^{1}$ Faculty of Economics, Universitas Negeri Medan, Indonesia

*Corresponding author. Email: imaipita@gmail.com

\begin{abstract}
This study aims to 1) mapping the pre-service teacher students knowledge related to mastery Technological, Pedagogical, Content Knowledge (TPACK); 2) mapping the quality of organizational support related to technology-oriented learning; and 3) mapping the performance of pre-service teacher candidates in implementing IT-integrated learning at the Faculty of Economics, Universitas Negeri Medan. This issue becomes important due to the increasing dependence of education and teaching on the use of Information Technology (IT). Especially after the Covid-19 pandemic, which has increased dependence on IT. The subjects of this study were pre-service teacher students with the criteria that they had completed the internship program, which is the teaching practice program in schools. Thus, the actual response is obtained based on students' experience teaching with the demands of technological integration. Data were collected by survey method through an electronic questionnaire. This study obtained 420 responses which were then analyzed by descriptive statistics. The results showed that the mastery of teacher candidate students' TPACK was at a moderate level. The same thing is also found in aspects of organizational support and the teaching performance of pre-service teacher students. Therefore, the Faculty of Economics, State University of Medan, has shown academic policies that support learning in the digital era. However, Higher Education should optimize various aspects so that prospective teacher students and/or alumni of the Faculty of Economics, Universitas Negeri Medan, can become competent teachers with adequate pedagogic competence in the digital era.
\end{abstract}

Keywords: TPACK, digital era, pedagogic, $21^{\text {st }}$ Century Learning.

\section{INTRODUCTION}

In the last two decades, educational researchers have been preoccupied with using information technology (IT) to innovate learning [1-4]. However, integrating IT in learning is a challenge in educational practice considering that teachers have to adapt to the new work environment and learn more about how to deliver learning through IT mediation [3-5]. Not a few teachers ultimately feel pressured and stressed due to the demands of IT integration in learning [6,7]. However, the availability of IT and its development that increasingly supports learning practices make teachers ideally more facilitated to innovate learning [8,9]. Thus, teachers cannot avoid using IT in their main tasks and functions and, of course, must accept to return to learning in developing their educational technology knowledge.
In responding to these developments, higher teacher education has the responsibility to prepare teachers to have adequate technological and pedagogic literacy in the digital era so that, in turn, they will be ready to organize 21 st-century learning. In addition to preparing teacher education learning content, universities must also have technical support in anticipating various obstacles while shifting from conventional learning culture to being IT-oriented [7]. With the readiness of content and infrastructure, educational institutions are expected to provide satisfactory IT-integrated academic services. Furthermore, learning experiences and IT interactions during learning are expected to produce optimal IT-integrated teaching performance for student-teacher candidates $[4,5,7]$.

This study aims to 1) map the mastery of prospective teacher students related to 
Technological, Pedagogical, Content Knowledge (TPACK), 2) mapping the quality of organizational support related to technology-oriented learning, and 3) mapping student teacher performance in implementing IT-integrated learning. In principle, previous researchers have widely studied the concept of IT literacy and mastery of learning content to implement learning in the 21st century [10-13]. However, Mishra and Koehler [14] formulated a knowledge framework that includes digital era pedagogy with parsimony but complex and complete terminology. The TPACK knowledge framework includes pedagogic mastery in teaching students, content related to the material to be taught, and technology related to tools and media used to teach content and practice teacher-defined pedagogic strategies [14-16]. With the mastery of that knowledge and the interaction of the three aspects of knowledge, Mishra and Kohler (2012) view that teachers will have readiness in carrying out learning in the digital era [10].

On the other hand, Li and Wang [7] revealed that schools and universities must have technical support to anticipate various obstacles teachers and students face in technology-mediated learning. The shift in learning and teaching from traditional to IT-oriented will result in various obstacles and slowdowns [4-6]. Therefore, technical support in terms of facilitation of learning, technical assistants, and involvement in system development will help schools and universities minimize the risk of irritation and failure of learning style transitions and work styles due to technology integration [7]. If teacher education institutions teach adequate digital era pedagogic knowledge plus the provision of professional development services, technical support, and optimal role participation in the academic community, it is predicted that these institutions will be able to produce teachers with relevant performance to carry out learning in the digital era.

\section{METHOD}

The subject of this study is a pre-service teacher in the Faculty of Economics, Universitas Negeri Medan, Indonesia. The criteria for prospective teacher students are students majoring in education who have completed internship programs. The internship program is the actual teaching practice program carried out in schools. The researcher assumed that the prospective teacher students had sufficient pedagogic knowledge from the lectures they had passed and had experience teaching in real classrooms. This study used a survey method to collect data. The research instrument was adapted from Mishra and Koehler (2006) for TPACK variables and Li and Wang (2001) for organizational support and performance variables. The data was collected through electronic questionnaires distributed randomly to the target respondents [17]. With this technique, this study has collected 420 data. The data collected were tabulated and analyzed with descriptive statistics [18].

\section{RESULT AND DISCUSSION}

\subsection{Demography of Sample}

Quantitative studies in this study were conducted by collecting primary data through surveys using questionnaires. The data shows that the representation of each teacher study program at the Faculty of Economics has been fulfilled with 420 responses collected. Some of the respondents are female. This composition does represent the composition of students from the Faculty of Economics, Universitas Negeri Medan, which women dominate. Furthermore, respondents are dominated by the age of 20-21, representing the final year students' age. So then, the composition of respondents has represented students from the four teaching study programs at the Faculty of Economics. Comprehensively, the demographics are presented in Table 1 below.

Table 1. Demografi Sample

\begin{tabular}{|c|c|c|c|c|}
\hline No & & abel & $\mathrm{n}$ & $\%$ \\
\hline \multirow[t]{3}{*}{1} & Gender & Male & 64 & $15,24 \%$ \\
\hline & & Female & 356 & $84,76 \%$ \\
\hline & & & 420 & $100 \%$ \\
\hline \multirow[t]{5}{*}{2} & Age & 18 & 27 & $6,43 \%$ \\
\hline & & 19 & 115 & $27,38 \%$ \\
\hline & & 20 & 130 & $30,95 \%$ \\
\hline & & 21 & 148 & $35,24 \%$ \\
\hline & & & 420 & $100 \%$ \\
\hline \multirow[t]{7}{*}{3} & $\begin{array}{l}\text { School } \\
\text { Background }\end{array}$ & $\begin{array}{l}\text { Senior High } \\
\text { School }\end{array}$ & 287 & $68,33 \%$ \\
\hline & & Vocational & & \\
\hline & & School & 104 & $24,76 \%$ \\
\hline & & Islamic & & \\
\hline & & Boarding & 29 & $6,90 \%$ \\
\hline & & School & & \\
\hline & & & 420 & $100 \%$ \\
\hline \multirow[t]{7}{*}{4} & Major & $\begin{array}{l}\text { Administration } \\
\text { Education }\end{array}$ & 52 & $12,38 \%$ \\
\hline & & Accounting & 92 & $2100 \%$ \\
\hline & & Education & 92 & $21,90 \%$ \\
\hline & & Business & 105 & $25,00 \%$ \\
\hline & & $\begin{array}{l}\text { Education } \\
\text { Economics }\end{array}$ & & \\
\hline & & Education & 171 & $40,71 \%$ \\
\hline & & & 420 & $100 \%$ \\
\hline
\end{tabular}

\subsection{Descriptive statistics}

This study lists the profiles of eleven variables that function to measure 1) the pedagogical ability of prospective teachers to integrate information 
technology (IT) in learning with the TPACK framework (Technological, Pedagogical, Content, Knowledge); 2) Organizational support to anticipate various problems in using IT; and 3) performance of the pre-service teacher in teaching. That eleven variables were analyzed with descriptive statistics on the data obtained and classified based on the three criteria above. Furthermore, the results of the descriptive statistics of the sixteen variables are listed in table 2 below.

Table 2. Descriptive Statistic

\begin{tabular}{|c|c|c|c|}
\hline No & Variable & Average & $\%$ \\
\hline & \multicolumn{3}{|l|}{ TPACK } \\
\hline 1 & Pedagogics Knowledge & 3,79 & $75,82 \%$ \\
\hline 2 & Content Knowledge & 3,77 & $75,39 \%$ \\
\hline 3 & $\begin{array}{l}\text { Technology Knowledge } \\
\text { Pedagogics and Content }\end{array}$ & 3,62 & $72,45 \%$ \\
\hline 4 & $\begin{array}{l}\text { Knowledge } \\
\text { Pedagogics and Technology }\end{array}$ & 3,69 & $73,72 \%$ \\
\hline 5 & $\begin{array}{l}\text { Knowledge } \\
\text { Technology and Content }\end{array}$ & 3,85 & $77,06 \%$ \\
\hline 6 & $\begin{array}{l}\text { Knowledge } \\
\text { Technological Pedagogical } \\
\text { Content Knowledge }\end{array}$ & 3,74 & $74,89 \%$ \\
\hline \multirow[t]{2}{*}{7} & (TPACK) & 3,76 & $75,28 \%$ \\
\hline & Organizational Support & & \\
\hline 13 & Learning Facility & 3,86 & $77,16 \%$ \\
\hline 14 & Technical Support & 3,71 & $74,21 \%$ \\
\hline 15 & Participation Facility & 3,87 & $77,33 \%$ \\
\hline \multicolumn{4}{|c|}{ Performance } \\
\hline 16 & Performance & 3,91 & $78,13 \%$ \\
\hline
\end{tabular}

\subsubsection{TPACK(Technological, Pedagogical, Content, Knowledge)}

a. Pedagogic knowledge (75.82\%) is the ability to develop learning tools, knowledge related to learning methods and models, learning styles and student characteristics, basic teaching skills, and the ability to make assessment instruments and evaluate learning outcomes.

b. Content Knowledge (75.39\%) is the mastery of prospective teachers related to the content or teaching materials according to their fields of expertise, including following scientific and practical developments in these teaching materials.

c. Technological Knowledge (72.45\%) is knowledge related to developing technologies, including the ability to use a variety of technologies such as computers, digital cameras, mobile devices, word and data processing software such as MS-Office packages, image and video processing such as Photoscape, Photoshop, Filmora, and the like.

d. Pedagogic and Content Knowledge (73.72\%) is learning management knowledge referring to content or teaching materials. In this aspect, prospective teachers can manage appropriate learning strategies according to the content they teach or have reasons based on teaching materials in developing learning strategies.

e. Pedagogic and Technological Knowledge $(77.06 \%)$ is knowledge related to using technology in implementing the chosen learning strategy. This means that prospective teachers can find out, choose and use the technology they need for learning. In addition, prospective teachers can also ensure that technology will improve the quality of their learning.

f. Knowledge of Technology and Content $(74.89 \%)$ is the knowledge of prospective teachers regarding how technology is the context and content of teaching materials so that prospective teachers can update teaching materials on an ongoing basis.

g. Knowledge of Pedagogics, Content, Technology $(75.28 \%)$ is a slice of mastery of pedagogic aspects, content, and technology so that teachers can integrate all three in learning. With this mastery of knowledge, prospective teachers are expected to be able to teach students by using technology, to be able to present up-todate and up-to-date teaching materials, and to optimize learning activities, not just using technology that has an immeasurable impact on learning and mastery of students' knowledge.

In general, in the TPACK aspect, respondents showed a moderate perception of mastery with a range of $72 \%-78 \%$. The highest mastery perception is found in the Pedagogic Knowledge and Technology variable, while the lowest is in the Technology Knowledge variable. However, the seven variables do not show a gap that is far apart, so that, in general, they are in relatively the same range. This condition is not statistically satisfactory. However, if reflecting on the limitations of the literature related to IT integration in learning and the lack of discussion related to IT integration in learning when student-teacher candidates study in educational courses, then the profile is quite good and has the potential to be improved. 


\subsubsection{Organizational Support}

a. Learning Facilitation (77.16\%) is a knowledgesharing service related to the use of IT in teaching activities. These services can occur informally in discussion forums, learning communities, classroom learning, or special service centers provided by campuses or schools.

b. Technical Support (74.21\%) is a service center specifically held to help prospective teachers related to technical problems in the use of elearning, learning management systems, network technicalities, etc.

c. Facilitation Engagement (77.33\%) is support, appreciation, and praise when using technology in learning activities. The form of appreciation can be given verbally or certain incentives. For example, in on-campus learning in teaching practice-oriented technology-oriented teacher candidates can be appreciated with good grades.

Responses to this aspect show moderate numbers. It is in the $74 \%-78 \%$ range. This condition is quite potential for institutions, both FE Unimed as LPTK and schools as internship locations, to control and anticipate stressors. The profile indicates that there has been supported for pre-service teachers to learn technology for learning. This support can occur in classroom learning, in community or student study groups, mentoring in apprenticeship schools, and technical services provided by campuses or schools. However, investigations related to this support should be analyzed further. To obtain a formulation of learning services and technical assistance to help prospective teachers master IT for systematic learning both in classroom learning and in student service centers on campus.

\subsubsection{Performance}

a. Performance $(78.13 \%)$ is the perception of prospective teacher students in learning activities carried out. This perception shows the highest number than the other variables, $78.13 \%$, although it has not reached $80 \%$. From the point of view of performance, the number of prospective teacher-students is also in a moderate position, namely $78.13 \%$. This figure is not encouraging enough to produce quality learning. It can be assumed that student-teacher candidates still have problems optimizing the use of IT in their learning process. This figure indicates that teacher education institutions need to update the curriculum related to digital era pedagogy by referring to the fulfillment of the knowledge that makes up TPACK. In addition, teacher education institutions also need to adjust the curriculum to the needs of certain IT utilizations relevant to the needs of learning in Indonesia and, in this case, specifically in economics and business. Furthermore, universities need to optimize technical assistance services that assist both lecturers and students in interacting with technology during the teaching and learning process so that the obstacles overcome by using technology can be overcome properly.

\section{CONCLUSION}

This study aims to 1) mapping pre-service teacher students knowledge related to Technological, Pedagogical, Content Knowledge (TPACK); 2) mapping the quality of organizational support related to technology-oriented learning; and 3) mapping the performance of student-teacher candidates in implementing IT-integrated learning for pre-service teacher candidates at the Faculty of Economics, Universitas Negeri Medan. The results showed that the student-teacher candidates had mastery of TPACK knowledge at a moderate level. This figure is unsatisfactory considering that prospective teacher students are directly faced with learning practices dominated by the use of IT, especially after the Covid-19 pandemic attack, which resulted in dependence on IT. This finding should be of particular concern for teacher education institutions to prepare students with complex competencies. Pre-service teacher candidates not only have to master pedagogic knowledge, content, and technology. But the knowledge of the interaction between that knowledge so that the teacher can determine the right pedagogic strategy to teach certain content and determine the right technology to carry out certain learning strategies and following the material or content being taught [14-16].

Furthermore, organizational support also shows a moderate number. This condition shows that, in general, universities already have organizational support to carry out IT-integrated learning and to teach how to learn and teach by using IT. However, there is still ample development space for the Faculty of Economics, Universitas Negeri Medan, to optimize organizational support to produce optimal IT-integrated learning. In this case, especially in the aspect of technical support. Previous research revealed that technical support is an important aspect of the migration from traditional teaching and learning to IT-mediated learning and teaching activities [7]. During the transition period, both teachers and students generally face various 
obstacles in using learning management systems (LMS), transfer of materials, development of learning videos, exam design and implementation, and various other uses of IT in learning activities.

Finally, from the performance point of view, preservice teacher candidates show a moderate level of performance. This aligns with the findings on mastery of TPACK knowledge and organizational support experienced by prospective teacher students. So it appears that the data pattern shows linearity in the three variables. However, as with the mastery of TPACK knowledge, the level of performance in this figure also indicates that prospective teacherstudent's teaching practice is less than optimal. This is presumably due to the lack of well-established student readiness in implementing IT-integrated learning. In fact, the practice of pursuit has been very demanding of IT integration. In addition, the Covid19 pandemic has forced learning activities to shift radically to fully online learning so that the pedagogic competence of the digital era of tips is needed.

In general, the Faculty of Economics, Universitas Negeri Medan, has prepared student teacher candidates to be ready to face IT-integrated learning at a moderate level. However, various aspects are possible to optimize, so that prospective teacher students master the pedagogy of the digital era optimally and, in turn, become superior and competitive teachers. Future research can examine the relationship between variables and or test experimentally how to produce complex higher education learning to produce quality learning experiences for prospective teachers in terms of mastery of TPACK. Thus, student-teacher candidates taught at the Faculty of Economics, State University of Medan, can show high work performance at the school where they will have a career in the future.

\section{ACKNOWLEDGMENT}

This research was funded by a PNBP research grant from the Universitas Negeri Medan.

\section{REFERENCES}

[1] Badia, A., Meneses, J., \& Sigalés, C., Teachers' perceptions of factors affecting the educational use of ICT in technology-rich classrooms. 2013.

[2] Kalolo, J. F., Digital revolution and its impact on education systems in developing countries. Education and Information Technologies, 24(1), 2019, pp 345-358.
[3] Christensen, R., \& Knezek, G., Validating a mobile learning readiness survey: Assessing teachers' dispositions toward adoption. Journal of Digital Learning in Teacher Education, 33(4), 2017, pp 148-159.

[4] Cochrane, T. D., Exploring mobile learning success factors. Alt-j, 18(2), 2010, 133-148.

[5] Sun, Y., Strobel, J., \& Newby, T. J.,The impact of student teaching experience on pre-service teachers' readiness for technology integration: A mixed methods study with growth curve modeling. Educational Technology Research and Development, 65(3), 2017, pp 597-629.

[6] Effiyanti, T., \& Sagala, G. H., Technostress among teachers: a confirmation of its stressors and antecedent. International Journal of Education Economics and Development, 9(2), 2018, pp 134-148.

[7] Li, L., \& Wang, X., Technostress inhibitors and creators and their impacts on university teachers' work performance in higher education. Cognition, Technology \& Work, 23(2), 2021, pp 315-330.

[8] Saari, A., \& Säntti, J., The rhetoric of the "digital leap" in Finnish educational policy documents. European Educational Research Journal, 17(3), 2017, pp 442-457.

[9] Copriady, J., Self-motivation as a mediator for teachers' readiness in applying ICT in teaching and learning. Procedia-Social and Behavioral Sciences, 176(0), 2015, pp 699-708.

[10] Hsu, P. S., \& Sharma, P., A systemic plan of technology integration. Educational Technology \& Society, 9(4), 2006, pp 173-184.

[11] Brown, D., \& Warschauer, M., From the university to the elementary classroom: Students' experiences in learning to integrate technology in instruction. Journal of Technology and Teacher Education, 14(3), 2006, pp 599-621.

[12] Lisowski, L., Lisowski, J. A., \& Nicolia, S., Infusing technology into teacher education: Doing more with less. Computers in the schools, 23(3), 2006, pp 71-92.

[13] Sagala, G. H., Zainal, A., \& Effiyanti, T., Attitude Toward Computer-Based Statistics Among Pre-Service Teacher Candidates. Proceedings of MAC, 2017, pp 366.

[14] Mishra, P., \& Koehler, M. J., Technological pedagogical content knowledge: A framework 
for teacher knowledge. Teachers college record, 108(6), 2006, pp 1017-1054.

[15] Koehler, M., \& Mishra, P., What is technological pedagogical content knowledge (TPACK)?. Contemporary issues in technology and teacher education, 9(1), 2009, 60-70.

[16] Graham, C. R., Theoretical considerations for understanding technological pedagogical content knowledge (TPACK). Computers \& Education, 57(3), 2011, pp 1953-1960.

[17] Cooper, D. R., Schindler, P. S., \& Sun, J. Business research methods (Vol. 9, 2006, pp. 1-744). New York: Mcgraw-hill.

[18] Field, A., Discovering statistics using IBM SPSS statistics. sage. 2013. 